\title{
KEWAJIBAN INDONESIA BERDASARKAN KETENTUAN YANG BERSAMAAN KONVENSI JENEWA 1949
}

\author{
Erlies S. Nurbani \\ Fakultas Hukum Universitas Mataram \\ Jalan Majapahit Nomor 62 Mataram. Lombok. \\ Email: erlisseptiana@unram.ac.id
}

\begin{abstract}
As a part of international community, which had ratify various of international agreements, Indonesia obliged to create national laws which compatible with international agreements. Since ratification of international agreements is not a final process which must comply by a state to abide the international agreements. The adjustment of national law whether with establish the new law or amendment the existed law, is repercussions of ratifications phase which state have to fulfil. One of Indonesia obligations, based on Geneva Conventions 1949 for the Protection of Victims of War, i.e common articles of Article 49 Geneva Convention I, Article 50 Geneva Convention II, Article 129 Geneva Convention III and Article 146 Geneva Convention IV is to establish national law on grave breaches of the convention and to prosecute the perpetrators. This article try to examine further on the Indonesia obligations based on th common articles and its implementation in Indonesia, after 60 years of Indonesia accession to the Geneva Conventions 1949 with the Law Number 59 Year 1958 on Indonesia Participation on all of Geneva Conventions 1949.
\end{abstract}

Key Words : Obligations, Common Articles, Geneva Conventions 1949

\section{A. PENDAHULUAN}

Pembukaan Undang-Undang Dasar Negara Republik Indonesia 1945 (UUD NRI 1945) menyatakan bahwa : “...ikut serta menjaga ketertiban dunia, yang berdasarkan kemerdekaan, perdamaian abadi dan keadilan sosial...." Keterlibatan Indonesia secara aktif dalam hubungan-hubungan internasional telah nampak bahkan sejak negara ini berdiri. Sumbangan pemikiran dalam pembentukan Konvensi Hukum Laut 1982 (United Nations Conventions on the Law of the Sea 1982) sehingga diadopsi dan diterimanya konsep negara kepulauan dan luas laut territorial dalam Konvensi Hukum Laut 1982 yang bersumber dari wawasan nusantara merupakan fakta sejarah yang tidak bisa diabaikan. Sejumlah undang-undang ratifikasi perjanjian internasional serta keterlibatan pasukan Garuda secara aktif pada daerah-daerah konflik di berbagai belahan dunia dalam rangka menjaga perdamaian internasional, merupakan bukti peran serta Indonesia dalam menjaga perdamaian dan keamanan dunia.

Sebagai konsekuensi dari peran aktif Indonesia tersebut, bahwa segala kesepakatan dalam bentuk perjanjian internasional yang telah ditandatangani dan diratifikasi, maka Indonesia harus menaati isinya, baik secara nasional maupun internasional. Salah satu perjanjian internasional yang penting dan telah diterima oleh pemerintah Indonesia adalah Konvensi Jenewa 1949 tentang perlindungan korban perang (International Conventions for the Protection of Victims of War). Pengesahan Konvensi Jenewa 1949 di Indonesia dilakukan dengan Undang-Undang Nomor 59 tahun 1958 tentang Ikut Serta 
Indonesia dalam seluruh Konpensi Jenewa 1949.

Tindakan pemerintah Indonesia untuk mengesahkan dan mempraktikan normanorma dalam Konvensi Jenewa 1949 merupakan promosi yang dapat dilakukan bagi negara-negara lain. Khususnya dalam masa-masa damai. Keterlibatan tersebut dapat menjadi model pembelajaran bagi negara lain, baik yang berpotensi untuk berperang atau tidak, untuk sama-sama menghormati dan melaksanakan isi dari Konvensi Jenewa 1949. Karena, kewajiban-kewajiban negara peserta sebagaimana yang tercantum dalam ke-empat Konvensi Jenewa 1949, tidak hanya berlaku pada saat perang, namun juga pada masa damai.

Salah satu kewajiban penting dalam Konvensi Jenewa, adalah apa yang dikenal dengan istilah common articles. Common articles adalah beberapa pasal dalam Konvensi Jenewa, yang dipandang penting dan mendasar sehingga perlu dicantumkan dalam setiap Konvensi Jenewa, baik diletakkan pada nomor pasal yang sama maupun dirumuskan dalam redaksi atau isi yang sama/hampir sama. ${ }^{1}$ Adapun beberapa permasalahan yang merupakan common articles adalah mengenai penghormatan terhadap konvensi, sengketa bersenjata non internasional, orang-orang yang dilindungi dan pengawasan konvensi.

Common articles yang menarik untuk mendapat perhatian seluruh negara peserta khususnyadalammasa damai adalahmengenai kewajiban negara peserta untuk menindak pelaku pelanggaran dan penyalahgunaan, dalam pengadilan nasionalnya. Mengenai hal tersebut diatur dalam Pasal 49 Konvensi Jenewa I, Pasal 50 Konvensi Jenewa II, Pasal 129 Konvensi Jenewa III dan Pasal 146 Konvensi Jenewa IV.

Adapun bunyi pasal-pasal tersebut adalah sama, yaitu sebagai berikut ${ }^{2}$ :

\footnotetext{
KGPH Haryomataram.(2005) Pengantar Hukum Humaniter, Jakarta: PT. Rajagrafindo Persada, hlm. 24.

${ }^{2}$ Direktorat Jenderal Hukum dan Perundang-undangan Departemen Kehakiman.(1999). Terjemahan Konvensi Jenewa 1949, Jakarta.
}

Pihak peserta Agung berjanji untuk menetapkan peraturan yang diperlukan untuk memberi sanksi pidana efektif terhadap orang-orang yang melakukan atau memerintahkan untuk melakukan salah satu diantara pelanggaran berat atas Konvensi ini sebagaimana ditentukan di dalam pasal berikut.

Tiap pihak peserta agung berkewajiban untuk mencari orang-orang yang disangka telah melakukan atau memerintahkan untuk melakukan pelanggaran-pelanggaran berat yang dimaksudkan, dan harusmengadili orangorang tersebut, dengan tidak memandang kebangsaannya. Pihak peserta Agung dapat juga, jika dikehendakinya, dan sesuai dengan ketentuan-ketentuan perundang-undangan sendiri, menyerahkan kepada Pihak Peserta Agung lain yang berkepentingan, orangorang tersebut untuk diadili, asal raja Pihak Peserta Agung itu dapat menunjukkan suatu perkara prima facie.

Tiap pihak peserta agung harus mengambil tindakan-tindakan yang perlu untuk memberantas selain pelanggaran berat yang ditentukan dalam pasal berikut, segala perbuatan yang bertentangan dengan ketentuan-ketentuan Konvensi ini.

Dalam segala keadaan, orang-orang yang dituduh harus mendapat jaminan-jaminan peradilan dan pembelaan yang wajar, yang tidak boleh kurang menguntungkan dari jaminan-jaminan yang diberikan oleh Konvensi Jenewa tentang Perlakuan Tawanan Perang tanggal 12 Agustus 1949 sebagaimana diatur dalam Pasal 105 dan seterusnya.

Pada pokoknya, ketentuan tersebut memberikan kewajiban kepada negara peserta untuk membuat undang-undang nasional yang mengatur mengenai pelanggaran berat (gross violations), mencari orang yang diduga melakukan pelanggaran berat dan mengadili pelaku pelanggaran berat tersebut. Adapun yang dimaksud dengan pelanggaran berat Konvensi Jenewa adalah sebagaimana yang diatur dalam Pasal 50 Konvensi Jenewa I, yaitu pembunuhan disengaja, penganiayaan atau perlakuan tidak berperikemanusiaan, 
termasuk percobaan biologis, menyebabkan dengan sengaja penderitaan besar atau luka berat atas badan atau kesehatan, serta pembinasaan yang meluas. ${ }^{3}$

Menjelang 60 tahun Indonesia mengaksesi Konvensi Jenewa 1949 dengan UndangUndang Nomor 59 Tahun 1958 tentang Ikut Serta Indonesia dalam seluruh Konpensi Jenewa 1949, penting untuk mengetahui sejauh mana penerapan Konvensi Jenewa 1949 di Indonesia. Telah menjadi rahasia internasional bahwa Indonesia enggan untuk menyelesaikan kasus-kasus pelanggaran berat $\mathrm{HAM}^{4}$ yang telah terjadi. Bahkan, keberadaan Undang-Undang Nomor 26 Tahun 2000 tentang Pengadilan HAM bahkan dianggap sebagai upaya nyata Indonesia untuk menghindari campur tangan internasional dalam urusan domestik terkait dengan kejahatan kemanusiaan. ${ }^{5}$

Negara peserta Konvensi Jenewa harus mengambil langkah-langkah guna menegakkan Konvensi Jenewa di negaranya. Indonesia telah mensahkan Konvensi Jenewa dengan dengan Undang-Undang Nomor 59 tahun 1958. Hal ini berarti bahwa Konvensi Jenewa 1949 telah diadopsi dan diterima menjadi undang-undang nasional Indonesia, yang memiliki kedudukan hukum yang sama dengan undang-undang lainnya.

Berdasarkan latar belakang diatas, maka yang menjadi permasalahan dalam artikel ini adalah : Bagaimanakah penerapan ketentuanketentuan yang bersamaan (common articles) sebagaimana diatur dalam Pasal 49 Konvensi Jenewa I, Pasal 50 Konvensi Jenewa II, Pasal 129 Konvensi Jenewa III dan Pasal 146 Kon-

\footnotetext{
${ }^{3}$ Ibid.

${ }^{4}$ Presiden Joko Widodo menyatakan bahwa Pemerintah sedang fokus untuk menyelesaikan 6 kasus pelanggaran HAM berat yang terjadi di masa lalu. Kasus-kasus tersebut antara lain Peristiwa 1965-1966, Penembakan Misterius 1982-1985, Peristiwa Talangsari Lampung 1989, Penghilangan Orang Secara Paksa 1997-1998, Kerusuhan Mei 1998, Peristiwa Trisakti, Semanggi I, Semanggi II. Kompas, 21 April 2016 diakses melalui https://ebooks.gramedia.com/ id/koran/kompas/pagi-21-apr-2016 pada tanggal 29 Januari 2018.

${ }^{5}$ Mahfud, Integrasi HAM Dan Hukum Humaniter Dalam Sistem Peradilan Ham Nasional Dalam Rangka Penerapan Peradilan Ham Terhadap Pelaku Kejahatan Kemanusiaan, Kanun Jurnal Ilmu Hukum No. 61, Th. XV (Desember, 2013)
}

vensi Jenewa IV di Indonesia?

\section{B. METODE PENELITIAN}

Metode penelitian yang digunakan dalam membahas permasalahan yang diangkat dalam makalah ini ialah metode kajian normatif, dengan data yang dianalisis berasal dari data sekunder yang diperoleh melalui penelusuran kepustakaan. Secara garis besar, dalam melakukan analisis, peneliti berfokus pada dua hal pokok, yaitu: pertama, objek berupa peraturan, terutama pada tingkat internasional, ${ }^{6}$ dan nasional yang berkaitan dengan perjanjian internasional, hukum humaniter dan hak asasi manusia serta laporan-laporan atau artikel terdahulu yang membahas mengenai perkembangan penegakan hukum humaniter internasional dan hukum hak asasi manusia di Indonesia.

Pendekatan yang digunakan dalam penelitian ini adalah pendekatan konseptual (conceptual approach) dan pendekatan perundang-undangan (statute approach). Statute approach adalah pendekatan yang beranjak dari peraturan perundang-undangan (dalam penelitian ini adalah konvensi atau perjanjian internasional) yang berkaitan dengan permasalahan yang di hadapi. Conceptual approach adalah pendekatan yang beranjak dari pandangan-pandangan dan doktrin-doktrin yang berkembang di dalam khazanah hukum humaniter internasional. Dengan mempelajari pandangan-pandangan dan doktrin-doktrin peneliti akan menemukan ide-ide yang melahirkan pengertianpengertian, konsep-konsep dan asas-asas hukum yang relevan dengan isu yang di hadapi. $^{7}$

\section{PEMBAHASAN}

\section{Kewajiban Indonesia Pasca Aksesi Kon- vensi Jenewa 1949}

${ }^{6}$ Endra Wijaya, dkk, Dinamika Upaya Melakukan Sinergi Antara Hukum Perdagangan Internasional Dan Hukum Lingkungan, Jurnal Hukum dan Peradilan Volume 6 Nomor 3, November 2017, hlm 495.

Erlies Septiana Nurbani.(2017). Perkembangan Teknologi Senjata dan Prinsip Proporsionalitas, Jurnal Ius (Kajian Hukum dan Keadilan) Volume 5 Nomor 1, hlm. 24-29 
Perjanjian internasional adalah perjanjian dalam bentuk dan nama tertentu yang diatur dalam hukum internasional yang dibuat secara tertulis serta menimbulkan hak dan kewajiban di bidang hukum (internasional/ penulis) publik $^{8}$. Oleh karena itu, untuk mengkualifikasi sebuah perjanjian adalah perjanjian internasional maka harus memenuhi persyaratan-persyaratan diatas.

Menurut Undang-Undang Nomor 24 tahun 2000 Tentang Perjanjian Internasional, ratifikasi atau pengesahan suatu perjanjian internasional dapat dilakukan dengan undangundang atau keputusan presiden. ${ }^{9}$ Pengesahan perjanjian internasional dilakukan dengan undang-undang apabila berkenaan dengan ${ }^{10}$ :

a. masalah politik, perdamaain, pertahanan, dan keamanan negara

b. perubahan wilayah atau penetapan batas wilayah negara Republik Indonesia;

c. kedaulatan atau hak berdaulat negara;

d. hak asasi manusia dan lingkungan hidup;

e. pembentukan kaidah hukum baru;

f. pinjaman dan/atau hibah luar negeri.

Dalam hukum internasional, dikenal istilah ratifikasi yang dalam konteks hukum nasional terdapat pada Pasal 1 huruf $b$ UndangUndang Nomor 24 Tahun 2000 tentang Perjanjian Internasional, menyatakan bahwa pengesahan adalah perbuatan hukum untuk meningkatkan diri pada suatu perjanjian dalam bentuk ratifikasi (ratification), aksesi (accession), dan penerimaan (acceptance) dan penyetujuan (approval).

Dalam konteks hukum Indonesia berdasarkan Pasal 1 huruf b Undang-Undang Nomor 24 Tahun 2000 tentang Perjanjian Internasional bahwa ratifikasi, aksesi penerimaan dan penyetujuan adalah bentukbentuk pengikatan diri Indonesia terhadap sebuah naskah perjanjian internasional. Walaupun dalam konteks hukum internasional, tidaklah demikian.

\footnotetext{
${ }^{8}$ Pasal 2 Vienna Convention on the Law of Treaties 1969

${ }^{9}$ Pasal 9 Undang-Undang Nomor 24 Tahun 2000 tentang Perjanjian Internasional

10 Pasal 10 Undang-Undang Nomor 24 Tahun 2000 tentang Perjanjian Internasional
}

Ratifikasi adalah pengesahan sebuah perjanjian internasional, apabila negara yang hendak mengesahkan adalah pihak pada perjanjian tersebut (parties to the convention) sedangkan aksesi adalah pernyataan keterikatan negara terhadap perjanjian internasional yang telah lebih dulu ada, dimana negara tersebut tidak turut menandatangani naskah perjanjian internasional. Atau dengan kata lain negara tersebut bukanlah pihak pada konperensi yang merumuskan perjanjian internasional tersebut. Sedangkan, penerimaan (acceptance) atau penyetujuan (approval) yaitu pernyataan menerima atau menyetujui dari negara-negara pihak pada suatu perjanjian intemasional atas perubahan perjanjian internasional tersebut.

Kewajiban utama negara setelah melakukan ratifikasi/aksesi/acceptance sebuah perjanjian internasional adalah ${ }^{11}$ :

1. Pertama, Indonesia harus menerjemahkan atau mentransformasikan kewajiban dalam perjanjian internasional ke dalam hukum nasional.Iniberartiberbagaiproduknasional yang bertentangan dengan ketentuan dalam perjanjian internasional wajib untuk diamendemen. Transformasi ini adalah untuk memastikan agar tidak ada ketentuan yangberbenturan(conflicting)antarahukum nasional dengan perjanjian internasional yang telah diratifikasi.

2. Kedua,konsekuensiyangharusdiperhatikan adalah kewajiban Indonesia memberikan laporan ke suatu lembaga yang ditentukan dalam perjanjian internasional. Dalam sejumlah perjanjian internasional yang bersifat multilateral terdapat kewajiban negara peserta untuk melaporkan kemajuan (progress) yang telah dilakukan. Sebelum meratifikasi perjanjian internasional perlu untuk diketahui kapasitas aparat penegak hukum. Hal ini karena bila perjanjian internasional telah diterjemahkan ke dalam hukum nasional tetapi tidak mampu

${ }^{11}$ Sadikin.(2009). Ratifikasi Perjanjian Internasional dalam Kaitannya dengan Program Legislasi Nasional, Makalah dalam FGD Ratifikasi OP CEDAW. 
ditegakkan oleh aparat, sama saja dengan Indonesia tidak menepati komitmennya.

Kesulitan terbesar dalam proses pengikatan diri pada suatu perjanjian internasional sesungguhnya adalah pada kajian implikasi perjanjian tersebut terhadap hukum nasional. Idealnya ketika pemerintah sudah memutuskan menandatangani suatu perjanjian internasional maka sebelumnya sudah dilakukan kajian implikasi tersebut sehingga ketika ratifikasi diajukan kepada DPR, perdebatan soal dampak dari ratifikasi terhadap hukum nasional sudah selesai. ${ }^{12}$

Ketika naskah perjanjian telah diratifikasi/ aksesi/disetujui/diterima maka tidak ada alasan lagi, khususnya secara nasional, perjanjian internasional tersebut tidak dapat dilaksanakan. Suatu negara, tidak dapat menyatakan tidak lagi terikat terhadap perjanjian internasional dengan alasan bertentangan dengan hukum nasionalnya. ${ }^{13}$ Sebab, "preview" hukum nasional terhadap perjanjian internasional yang akan diratifikasi, dianggap telah dilakukan. Oleh karena itu, negara wajib untuk menghormati dan menaati seluruh isi dari perjanjian internasional yang telah diratifkasinya. ${ }^{14}$

Demikian pula dengan kewajiban Indonesia setelah mengesahkan Konvensi Jenewa 1949, 60 tahun yang lalu dengan Undang-Undang Nomor 59 tahun 1958 tentang Aksesi Negara RI terhadap Ke-empat Konvensi Jenewa tanggal 12 Agustus 1949. Dengan ratifikasi/ aksesi/approval/acceptance maka terbukalah kewajiban negara selanjutnya menurut perjanjian internasional, yaitu pemberlakuan

12 Beberapa judicial review pernah diajukan kepada Mahkamah Konstitusi terhadap undang-undang yang lahir dari ratifikasi perjanjian internasional. Seperti, judicial review terhadap undang-undang ratifikasi Piagam ASEAN, dan bahkan yang terbaru saat ini adalah judicial review tehadap undang-undang tentang Perjanjian Internasional (Februari, 2018)

${ }^{13}$ Pasal 26 Konvensi Wina tentang Perjanjian Internasional 1969

${ }^{14} \mathrm{Hal}$ ini karena dasar berlaku dan mengikatnya perjanjian internasional adalah asas Pancta Sunt Servanda. Pancta Sunt Servanda menyatakan bahwa setiap perjanjian harus ditaati. Prinsip ini merupakan prinsip fundamental dalam hukum internasional dan menjadi norma imperatif dalam praktik perjanjian internasional. Pasal 26 Konvensi Wina 1969 tentang Pembuatan Perjanjian Internasional antara Negara dengan Negara. ketentuan-ketentuan dalam perjanjian internasional ke dalam hukum nasional dari negara peserta.

Undang-undang ratifikasi tersebut tidak serta merta menjadikan perjanjian internasional menjadi hukum nasional Indonesia, undang-undang ratifikasi hanya menjadikan Indonesia sebagai negara terikat terhadap perjanjian internasional tersebut. Untuk perjanjian internasional tersebut berlaku perlu dibuat undang-undang yang lebih spesifik mengenai perjanjanjian internasional yang diratifikasi, contoh Indonesia meratifikasi International Covenant on Civil and Political Rights melalui undangundang, maka selanjutnya Indonesia harus membuat undang-undang yang menjamin hak-hak yang ada di covenant tersebut dalam undang-undang yang lebih spesifik. ${ }^{15}$

Konvensi Jenewa 1949 pada dasarnya adalah mengatur tentang perlindungan korban perang dalam konflik bersenjata internasional, bukan berarti bahwa Indonesia dalam masa damai tidak berkewajiban untuk menaatinya. Sebab, ada beberapa kewajiban yang harus dilaksanakan oleh negara, khususnya pada masa damai. Oleh karena itu, UndangUndang Nomor 59 Tahun 1960 tentang Aksesi Konvensi Jenewa 1949 bukanlah langkah akhir dalam pemberlakuan Konvensi Jenewa di Indonesia. Melainkan, merupakan awal dari langkah panjang untuk memberlakukan Konvensi Jenewa 1949 di dalam wilayah teritorial Indonesia, sebagaimana diwajibkan kepada seluruh negara peserta dari Konvensi Jenewa 1949.

\section{Selayang Pandang Konvensi-Konvensi Je- newa 1949}

Dari berbagai definisi hukum humaniter dibedakan hukum humaniter dalam arti sempit dan luas yang meliputi Konvensi Jenewa (dalam arti sempit), Hukum Perang dan HAM (dalam arti luas) berarti termasuk

15 Dina Sunyowati.(2013). Hukum Internasional Sebagai Sumber Hukum Dalam Hukum Nasional (Dalam Perspektif Hubungan Hukum Internasional Dan Hukum Nasional Di Indonesia), Jurnal Hukum dan Peradilan, Volume 2 Nomor 1 Maret, hlm. 83 
Hukum Den Haag, Hukum Jenewa bahkan termasuk aturan yang tidak tertulis sekalipun. ${ }^{16}$ Pendapat selanjutnya mengenai hukum humaniter, Haryomataram membagi hukum humaniter menjadi dua aturan-aturan pokok, yaitu: a) Hukum yang mengatur mengenai cara dan alat yang boleh dipakai untuk berperang (Hukum Den Haag/ The Hague Laws); b) Hukum yang mengatur mengenai perlindungan terhadap kombatan dan penduduk sipil dari akibat perang (Hukum Jenewa/The Geneva Laws). ${ }^{17}$

Sementara itu Starke mengatakan sebagai berikut:"As will appear post, the appellation "laws of war" has been replaced by that of "international humanitarian law". Starke mengidentikkan law of war dengan international humanitarian law. Starke memberikan definisi law of war sebagai berikut: " The laws of war consist of the limit set by international law within with the force required to overpower the enemy may be used, and the principles thereunder governing the treatment of individual in the course of war and armed conflict. ${ }^{18}$

Perkembangan Hukum Jenewa di dunia tidak telepas dari peran Komite Internasional Palang Merah (International Comitte of the Red Cross). Konvensi Jenewa 1864 sedikit banyak dipengaruhi oleh karya Henry Dunant, yang merupakan Bapak Palang Merah, yaitu sebuah buku tentang dampak dan akibat peperangan di Solverino, Italia Utara (Memory of Solverino). Buku tersebut menceritakan tentang masalah utama setelah peperangan berakhir. Penderitaan oleh anggota angkatan bersenjata pada saat peperangan karna tidak tersedianya pertolongan yang dibutuhkan. Oleh karena itu, Henry Dunant dalam Memory of Solverino mengusulkan untuk dibentuk sebuah badan netral yang bertujuan untuk menolong pada saat perang dan perjanjian antar negara mengenai hal tersebut.

\footnotetext{
${ }^{16}$ Erwin, Pengabaian Distinction Principle dalam Situasi Blokade oleh Israel di Jalur Gaza, tanpa tahun, tanpa penerbit.

${ }^{17} \mathrm{KGPH}$ Haryomataram, Op.Cit.

18 Starke, JG.(1977). An Introduction to International Law, London: Butterworths, hlm.558.
}

Konvensi Jenewa 1864 menjadi instrumen hukum pertama tentang kesepakatan negara di bidang Hukum Humaniter Internasional dan menjadi perjanjian pertama yang terbuka bagi setiap negara untuk ikut serta di dalamnya. Setelah itu, cukup banyak pertemuan diplomatik dan antarnegara yang diselenggarakan secara teratur dan menghasilkan perjanjian-perjanjian lainnya di bidang Hukum Humaniter Internasional. ${ }^{19}$

Setelah Perang Dunia II, yaitu tahun 19451948, dunia melihat terbentuknya peradilan internasional terhadap penjahat perang, yaitu di Tokyo dan Nuremberg atas prakarsa para pemenang perang (Victor's Justice ${ }^{20}$ ). Sementara itu Konvensi Jenewa 1864 mengalami perbaikan dan penyempurnaan terakhir dengan terbentuknya Ke-empat Konvensi-Konvensi Jenewa 1949 tentang perlindungan korban perang. ${ }^{21}$

Adapun secara lebih terperinci keempat Konvensi Jenewa 1949 tersebut, adalah :

a. Konvensi Jenewauntuk Perbaikan Keadaan yang Luka dan Sakit dalam Angkatan Bersenjata di Medan Pertempuran Darat (Geneva Convention for the Amelioration of the Condition of the Wounded and Sick in Armed Forces in the Field).

b. Konvensi Jenewa untuk Perbaikan Keadaan Anggota Angkatan Bersenjata di Laut yang Luka, Sakit dan Korban Karam (Geneva Convention for the Amelioration of The Condition of The Wounded an Sick in Armed Forces at the Sea).

c. Konvensi Jenewa mengenai perlakuan tawanan perang (The Geneva Convention relative to the Treatment of Prisoner of War).

d. Konvensi Jenewa mengenai perlindungan orang sipil di waktu perang (The Geneva Convention relative to the Protection of Civillian Person in Time of War)

Tahun 1977 ditandai dengan dibentuknya dua perjanjian internasional yang merupakan

\footnotetext{
19 Rina Rusman dalam Ambarwati, dkk.(2009). Hukum Humaniter Internasional (Dalam Studi Hubungan Internasional), Jakarta: Rajagrafindo Persada, hlm.32.

${ }^{20}$ Victor's Justice atau keadilan pemenang adalah keadilan menurut negara pemenang perang.

${ }^{21}$ Rina Rusman, Op.Cit
} 
tambahan atas Konvensi Jenewa 1949. Perjanjian tersebut adalah Protokol Tambahan I/1977 tentang Perlindungan Korban Perang pada situasi sengketa bersenjata internasional dan Protokol Tambahan II/1977 tentang Perlindungan Korban Perang pada situasi sengketa bersenjata non-internasional.

Protokol I dan II merupakan tambahan dari Konvensi-Konvensi Jenewa 1949. Penambahan itu dimaksudkan sebagai penyesuaian terhadap perkembangan pengertian sengketa bersenjata, pentingnya perlindungan yang lebih lengkap bagi mereka yang luka, sakit dan korban karam dalam suatu peperangan, serta antisipasi terhadap perkembangan mengenai alat dan cara berperang.

Penerapan Common Articles Konvensi Jenewa 1949 Tentang Penyalahgunaan Dan Pelanggaran Konvensi

Ketentuan yang bersamaan (common articles) adalah beberapa pasal dalam Konvensi Jenewa, yang dipandang penting dan mendasar sehingga perlu dicantumkan dalam setiap Konvensi Jenewa, baik diletakkan pada nomor pasal yang sama maupun dirumuskan dalam redaksi atau isi yang sama/hampir sama. ${ }^{22}$ Ketentuan-ketentuan yang bersamaan ini ada yang dimuat dalam pasal-pasal yang sama pada keempat konvensi dan ada pula pada pasal-pasal yang berlainan. Common articles diberikan definisi berbeda oleh ahliahli hukum internasional di Indonesia. Ada yang menyebutnya ketentuan-ketentuan yang bersamaan (yang merupakan terjemahan dalam bahasa indonesia), pasal-pasal kembar, dll.

Penempatan ketentuan yang bersamaan dalam seluruh Konvensi Jenewa menunjukkan penekanan pentingnya kewajiban bagi negara untuk menghormati ketentuan-ketentuan Konvensi. ${ }^{23}$ Ketentuanketentuan yang bersamaan dalam Konvensi Jenewa mencerminkan hal-hal yang menurut

\footnotetext{
${ }^{22} \mathrm{KGPH}$ Hayomataram, Op.Cit

23 Yustina Trihoni Nalesti Dewi.(2013). Kejahatan Perang dalam Hukum Nasional dan Hukum Internasional, Jakarta: Rajagrafindo Persada, hlm.79.
}

para perancang konvensi dianggap cukup signifikan "untuk mendapatkan penekanan melalui pengulangan". ${ }^{24}$

Ketentuan yang bersamaan ini terbagi dalam tiga golongan, yaitu ${ }^{25}$ :

a. Ketentuan-ketentuan umum

b. Ketentuan-ketentuan mengenai hukuman terhadap penyalahgunaan konvensi

c. Ketentuan-ketentuan pelaksanaan dan penutup (akhir)

Dikarenakan pentingnya sifat ketentuan yang diatur dalam common articles untuk ditaati oleh negara-negara pihak, dapat dikatakan bahwa sifat memaksa dalam common articles merupakan indikasi dari karakter obligations erga omnes (kewajiban semua negara untuk mematuhi dan menegakkannya).

Obligation erga omnes memberikan kewajiban kepada semua negara untuk melaksanakan ketentuan-ketentuan dalam Konvensi Jenewa, termasuk di dalamnya melakukan penghukuman terhadap pelaku pelanggaran berat Konvensi. Selain itu, sejumlah 192 dari 193 negara (hanya Nauru, Kepulauan Pasifik Selatan yang tidak meratifikasi Konvensi Jenewa 1949) di dunia telah meratifikasi Konvensi Jenewa $1949^{26}$ yang memberikan arti bahwa semua negara terikat memenuhi ketentuan Konvensi Jenewa 1949 karena ratifikasi memberikan implikasi hukum untuk mematuhi ketentuan-ketentuan yang ada di dalam Konvensi. ${ }^{27}$

Beberapa pasal yang merupakan ketentuan yang bersamaan (common articles) Konvensi Jenewa 1949, adalah :

a. Pasal 1 tentang Ketentuan Umum

b. Pasal 2 tentang Lingkup Berlakunya Konvensi

c. Pasal 3 tentang Sengketa Bersenjata Internasional.

\footnotetext{
${ }^{24}$ Gary D. Solis dalam Knut Do“rann and Jose Serralvo, Common Article 1 to the Geneva Conventions and the Obligation to Prevent International Humanitarian Law Violations, International Review of the Red Cross, hlm.5.

${ }^{25}$ Mochtar Kusumaatmadja.(1986). Konvensi-Konvensi Palang Merah Tahun 1949, Bandung: Binacipta, hlm. 16.

${ }^{26}$ Roichatul Aswidah dan Sondang Friska Simanjuntak, dalam Yustina Trihoni Nalesti Dewi, hlm.80.

${ }^{27}$ Ibid.
} 
d. Pasal 13 Konvensi I/II/III dan Pasal 41 Konvensi IV tentang Orang-orang yang dilindungi

e. Pasal 6 tentang Persetujuan Khusus

f. Pasal7KonvensiI/II/IIIdanPasal8Konvensi IV tentang Larangan Pelepasan Hak

g. Pasal8KonvensiI/II/IIIdanPasa19Konvensi IV tentang Pengawasan Pelaksanaan Konvensi

h. Pasal 46 Konvensi I, Pasal 47 Konvensi II, Pasal 13 Konvensi III dan Pasal 33 Konvensi IV tentang Larangan Melakukan Pembalasan

i. Pasal 47 Konvensi I, Pasal 48 Konvensi II, Pasal 127 Konvensi III, dan Pasal 144 Konvensi IV tentang Penyebarluasan Konvensi

j. Pasal 49 Konvensi I, Pasal 50 Konvensi II, Pasal 129 Konvensi III dan Pasal 146 Konvensi IV tentang Ketentuan Hukum terhadap Penyalahgunaan dan Pelanggaran

k. Pasal 55 tentang Ketentuan Penutup

Untuk membatasi pembahasan, artikel ini terfokus pada common articles Pasal 49 Konvensi Jenewa I, Pasal 50 Konvensi Jenewa II, Pasal 129 Konvensi Jenewa III dan Pasal 146 Konvensi Jenewa IV mengatur tentang kewajiban negara peserta untuk menindak pelaku pelanggaran dan penyalahgunaan dalam pengadilan nasionalnya. Adapun bunyi pasal-pasal tersebut adalah sama, yaitu sebagai berikut ${ }^{28}$ :

Pihak peserta Agung berjanji untuk menetapkan peraturan yang diperlukan untuk memberi sanksi pidana efektif terhadap orang-orang yang melakukan atau memerintahkan untuk melakukan salah satu diantara pelanggaran berat atas Konvensi ini sebagaimana ditentukan di dalam pasal berikut.

Tiap pihak peserta agung berkewajiban untuk mencari orang-orang yang disangka telah melakukan atau memerintahkan untuk melakukan pelanggaran-pelanggaran berat yang dimaksudkan, danharusmengadiliorang-

${ }^{28}$ Direktorat Jenderal Hukum dan Perundang-undangan Departemen Kehakiman.(1999). Terjemahan Konvensi Jenewa 1949, Jakarta. orang tersebut, dengan tidak memandang kebangsaannya. Pihak peserta Agung dapat juga, jika dikehendakinya, dan sesuai dengan ketentuan-ketentuan perundang-undangan sendiri, menyerahkan kepada Pihak Peserta Agung lain yang berkepentingan, orangorang tersebut untuk diadili, asal raja Pihak Peserta Agung itu dapat menunjukkan suatu perkara prima facie.

Tiap pihak peserta agung harus mengambil tindakan-tindakan yang perlu untuk memberantas selain pelanggaran berat yang ditentukan dalam pasal berikut, segala perbuatan yang bertentangan dengan ketentuan-ketentuan Konvensi ini.

Dalam segala keadaan, orang-orang yang dituduh harus mendapat jaminan-jaminan peradilan dan pembelaan yang wajar, yang tidak boleh kurang menguntungkan dari jaminan-jaminan yang diberikan oleh Konvensi Jenewa tentang Perlakuan Tawanan Perang tanggal 12 Agustus 1949 sebagaimana diatur dalam Pasal 105 dan seterusnya.

Indonesia sebagai negara yang telah mengaksesi Konvensi Jenewa 1949 dengan Undang-Undang Nomor 59 Tahun 1958 mempunyai kewajiban untuk menghormati Konvensi Jenewa 1949. Sebagaimana yang diaturdalam common articles Pasal 1 Konvensi Jenewa I 1949, menyatakan bahwa "pihakpihak peserta Agung berkewajiban untuk menghormati dan menjamin penghormatan atas Konvensi ini dalam setiap keadaan".

Frasa "menjamin" dalam Pasal 1 berarti bahwa Negara harus memerintahkan kepada petugas sipil dan militer untuk menaati konvensi ini, Negara harus mengawasi pelaksanaanperintahtersebutdanNegaraharus mengambiltindakan jika terjadi pelanggaran..$^{29}$ Kata "menghormati" juga berarti negara yang bersangkutan harus melaksanakan ketentuanketentuan yang ada di dalam Konvensi. Sedangkan "menjamin penghormatan" berarti negara harus melakukan tindakantindakan yang diperlukan apabila terjadi pelanggaran terhadap ketentuan-ketentuan

${ }^{29}$ Arlina Permanasari.(1999). Pengantar Hukum Humaniter, Jakarta: ICRC, hlm.181-182. 
Konvensi, termasuk menjatuhkan sanksi apabila diperlukan. ${ }^{30}$

Salah satu kewajiban negara untuk menjamin penghormatan terhadap konvensi Jenewa adalah kewajiban untuk menyebarluaskan Konvensi Jenewa, baik di kalangan militer maupun sipil. Disamping itu cukup banyak tindakan-tindakan lain yang perlu dipersiapkan di masa damai untuk mengantisipasi kerugian dan penderitaan akibat perang untuk menjamin penghormatan terhadap Konvensi Jenewa. Termasuk kewajiban negara untuk membuat peraturan nasional yang memuat sanksi hukum bagi setiap orang atau warga negaranya yang melanggar. ${ }^{31}$

Berdasarkan Pasal 49 Konvensi Jenewa I, Pasal 50 Konvensi Jenewa II, Pasal 129 Konvensi Jenewa III dan Pasal 146 Konvensi Jenewa IV, maka Indonesia berkewajiban :

a. Membuat hukum pidana yang menjadi saranapenghukuman bagisetiap orangyang melakukan kejahatan berat Konvensi

b. Mencari, menghukum atau mengekstradisi setiap orang yang melakukan atau memberi perintah kejahatan berat tanpa memandang kewarganegaraannya, termasuk mereka yang menyebabkan kegagalan untuk bertindak manakala mereka berkewajiban melakukan hal tersebut.

c. Bekerjasama dengan negara lain dalam penghukuman kejahatan perang

Negara yang telah meratifikasi Konvensi Jenewa diwajibkan untuk menerbitkan suatu Undang-undang nasional yang memberikan sanksi pidana efektif kepada setiap orang yang melakukan atau memerintah untuk melakukan pelanggaran berat terhadap Konvensi. Mekanisme yang terdapat pada ketentuan ini adalah suatu mekanisme dimana penegakan HHI yang dilaksanakan berdasarkan suatu proses peradilan nasional. Artinya, apabila terjadi kasus pelanggaran hukum humaniter maka si pelaku akan dituntut dan dihukum berdasarkan peraturan perundangan nasional dan dengan mengunakan mekanisme peradilan nasional yang bersangkutan.

\footnotetext{
${ }^{30}$ Ibid.

${ }^{31}$ Rina Rusman, Op.Cit.
}

Ketentuan dalam Konvensi Jenewa membawa makna penting yang lain dalam kerangka menjamin agar pelaku pelanggaran berat diadili dan memikul konsekuensi hukum yang semestinya. Jaminan ini dilakukan melalui pengaturan tentang kewajiban negara untuk mengadili tersangka pelaku pelanggaran berat tanpa memandang kewarganegaraanya yang disertai dengan kemungkinan negara pihak yang bersangkutan menyerahkan tersangka itu ke negara pihak lain yang dianggap berkepentingan.

Pengaturan ini menjadi penting karena bergeser dari konsep jurisdiksi nasionalitas yang sebelumnya cukup kuat dianut negaranegara dalam konteks pelanggaran hukum perang. Melalui ketentuan ini, seorang warga negara asing pun dapat diadili di suatu negara kalau ia disangka melakukan pelanggaran berat terhadap Konvensi Jenewa 1949. ${ }^{32}$

Untuk mencegah negara lain mengadili berkaitan dengan pelanggaran berat yang dilakukan oleh seorang warganegara, maka negara yang berdaulat harus dapat membentuk undang-undang nasional serta peradilan yang mampu dan mau mengadili siapa saja yang terbukti telah melakukan kejahatan-kejahatan yang telah diatur dalam Konvensi Jenewa 1949.

Pembuatan hukum dan badan peradilan nasional merupakan kewajiban Indonesia berdasarkan common articles dalam Pasal 49 Konvensi Jenewa I, Pasal 50 Konvensi Jenewa II, Pasal 129 Konvensi Jenewa III dan Pasal 146 Konvensi Jenewa IV. Namun, sejauh ini terdapat sangat sedikit undang-undang yang secara spesifik mengadopsi jenis-jenis kejahatan yang diatur dalam common articles Konvensi Jenewa dan dengan nomenklatur yang berbeda.

Menurut Yustina Trihoni Nalesti Dewi, belum ada satupun peraturan perundangundangan yang merupakan operasionalisasi dari Undang-Undang Nomor 59 Tahun 1958 dan belum ada satupun juga keputusan pengadilan nasional yang merujuk kepada

${ }^{32}$ Arie Siswanto, Hukum Pidana Internasional, Yogyakarta: Andi, hlm. 174 
Undang-Undang Nomor 59 Tahun 1958 sebagaidasarhukumdalammemutus perkara. ${ }^{33}$ Dalam praktik hukum nasional, Indonesia terkadang menunda untuk membuat national implementing legislation seperti halnya atas kewajiban untuk membuat peraturan pidana untuk menghukum pelaku kejahatan seperti yang ditentukan oleh Konvensi Jenewa 1949 yang sudah diratifikasi oleh pemerintah bersama DPR. ${ }^{34}$ Sebagaimana yang terjadi pada kasus Abilio Soares yang diadili oleh Pengadilan HAM Ad Hoc di Pengadilan Negeri Jakarta Pusat, Majelis Hakim menyatakan bahwa apa yang terjadi di Timor Timur merupakan pelanggaran terhadap common articles 3 Konvensi Jenewa 1949. ${ }^{35}$ Bebasnya seluruh pelaku pelanggaran HAM berat pada kasus Timor Timur dikarenakan oleh tidak adanya peraturan pidana untuk menghukum pelaku, sebagaimana yang diamanatkan oleh Konvensi Jenewa 1949.

Indonesia mengatur mengenai beberapa pelanggaran berat hukum humaniter di dalam undang-undang pengadilan HAM. Jenis-jenis kejahatan didalam Konvensi Jenewa 1949 diadopsi dalam undang-undang tersebut, secara parsial. Hal ini dapat dilihat dalam Konvensi Jenewa 1949 dimana kejahatan terhadap kemanusiaan ini diistilahkan dengan pelanggaran berat (grave breaches), sebagaimana diatur dalam Pasal 50 Konvensi Jenewa $\mathrm{I}^{36}$ :

"Pelanggaran-pelanggaran berat (grave breaches) yang dimaksudkan oleh Pasal yang terdahulu ialah pelanggaran-pelanggaran yang meliputi perbuatan-perbuatan berikut, apabila dilakukan terhadap orang atau milik yang dilindungi oleh Konvensi : pembunuhan disengaja, penganiayaan atau perlakuan tak berperikemanusiaan, ${ }^{37}$ termasuk percobaan

\footnotetext{
${ }^{33}$ Yustina Trihoni Nalesti Dewi, Op.Cit, hlm.67.

${ }^{34}$ Ibid.

${ }^{35}$ Lina Hastuti.(2012). Pengadilan Hak Asasi Manusia Sebagai Upaya Pertama Dan Terakhir Dalam Penyelesaian Pelanggaran Berat Hak Asasi Manusia Di Tingkat Nasional, Jurnal Dinamika Hukum Vol. 12 No. 3 September, hlm.396

${ }^{36}$ Direktorat Jenderal Hukum dan Perundang-undangan Departemen Kehakiman, Op.Cit.

37 Diadopsi sebagai bagian dari kejahatan genosida (genocides) dalam Undang-Undang Nomor 26 Tahun 2000
}

biologis, menyebabkan dengan sengaja penderitaan besar atau luka berat atas badan atau kesehatan, serta pembinasaan yang luas dan tindakan pemilikan atas harta benda yang tidak dibenarkan ${ }^{38}$ oleh kepentingan militer dan yang dilaksanakan dengan melawan hukum".

Undang-Undang Nomor 26 Tahun 2000 Tentang Pengadilan Hak Asasi Manusia Sebagai "Usaha Setengah Hati" Dalam Menegakkan Hukum Humaniter Internasional di Indonesia

Pengadilan Hak Asasi Manusia dibentuk berdasarkan Undang-Undang Nomor 26 Tahun 2000 tentang Pengadilan Hak Asasi Manusia. Keberadaan Undang-Undang Nomor 26 Tahun 2000 Tentang Pengadilan HAM sebagai perbaikan dari Perpu Nomor 1 Tahun 1999 Tentang Pengadilan HAM sebelumnya, merupakan reaksi Indonesia terhadap respon dunia internasional yang ingin mengadili orang-orang yang disangkakan melakukan kejahatan terhadap kemanusiaan di Timor-Timur paska jejak pendapat. Bangsa Indonesia secara terhormat memutuskan untuk menyelesaikan sendiri persoalan tersebut melalui pengadilan nasional, yang substansi hukumnya sebagian besar disesuaikan dengan Rome Statute 1948 tentang International Criminal Court (ICC). ${ }^{39}$ ICC merupakan pengadilan bersifat permanen yang menuntut dan mengadili kejahatan internasional yaitu kejahatan terhadap kemanusiaan (crimes against humanity), kejahatan perang (war crimes), genosida (genocides), dan kejahatan agresi (agression).

Di dalam penjelasan Rancangan UndangUndang Pengadilan HAM, disebutkan dengan jelas pengajuan RUU tentang Pengadilan HAM, adalah ${ }^{40}$ :

\footnotetext{
tentang Pengadilan HAM

38 Diadopsi sebagai bagian dari kejahatan terhadap kemanusiaan (crimes against humanity) dalam Undang-Undang Nomor 26 Tahun 2000 tentang Pengadilan HAM

${ }^{39}$ Muladi.(2003). Peradilan Hak Asasi Manusia Dalam Konteks Nasional dan Internasional. Artikel Lepas, Jakarta , hlm. 7

${ }^{40}$ Dalam Yustina Trihoni Nalesti Dewi, Op.Cit, hlm.107
} 
a. Untuk mewujudkan tanggung jawabbangsa Indonesia sebagai salah satu anggota PBB. Dengan demikian, merupakan salah satu misi yang mengembangkan tanggung jawab moral dan hukum dalam menjunjung tinggi dan melaksanakan Deklarasi HAM yang dittapkan oleh Perserikatan BangsaBangsa, serta yang terdapat dalam berbagai instrumen hukum lainnya yang mengatur mengenai HAM, yang telah dan/atau diterima oleh negara Indonesia

b. Dalam rangkamelaksanakan TAPMPR No. XVII/MPR/1998 tentang HAM dan sebagai tindak lanjut dari Pasal 104 ayat (1) UU Nomor 39 Tahun 1999

c. Untuk mengatasi keadaan yang tidak menentu di bidang keamanan dan ketertiban umum, termasuk perekonomian nasional. Keberadaan pengadilan HAM ini sekaligusdiharapkan dapatmengembalikan kepercayaan masyarakat dan dunia internasional terhadap penegakan hukum dan jaminan kepastian hukum mengenai penegakan HAM di Indonesia.

Pelanggaran HAM yang berat menurut Pasal 1 angka 2 diartikan sebagai pelanggaran HAM sebagaimana dimaksud dalam undang-undang tersebut, terdiri atas kejahatan genosida dan kejahatan terhadap kemanusiaan. ${ }^{41}$ Walaupun keberadaan Pengadilan HAM merupakan politik nasional untuk menghindari peradilan internasional di dalam territorial negara Indonesia, namun pemerintah tidak sungguh-sungguh mengadopsi jenis-jenis kejahatan yang menjadi yurisdiksi ICC. Tidak diaturnya jenis kejahatan agresi dan kejahatan perang dalam Undang-Undang Nomor 26 Tahun 2000, merupakan salah satu aspek yang melemahkan kinerja Pengadilan HAM. Selain ketiadaan hukum acara tersendiri, sistem tanggung jawab komando, dan lain-lain.

Lebih lanjut, definisi tentang kejahatan genosida dan kejahatan terhadap kemanusiaan diatur dalam Pasal 8 Undang-Undang Nomor 26 Tahun 2000, yaitu sebaga berikut :

${ }^{41}$ Pasal 6 dan 7 Undang-Undang Nomor 26 Tahun 2000 tentang Pengadilan Hak Asasi Manusia
Kejahatan genosida adalah setiap perbuatan yang dilakukan dengan maksud untuk menghancurkan atau memusnahkan seluruh atau sebagian kelompok bangsa, ras, kelompok etnis, kelompok agama, dengan cara :

a. membunuh anggota kelompok;

b. mengakibatkan penderitaan fisik atau mentalyangberatterhadapanggota-anggota kelompok;

c. menciptakan kondisi kehidupan kelompok yang akan mengakibatkan kemusnahan secara fisik baik seluruh atau sebagiannya;

d. memaksakan tindakan-tindakan yang bertujuan mencegah kelahiran di dalam kelompok;

e. atau memindahkan secara paksa anak-anak dari kelompok tertentu ke kelompok lain.

Kejahatan terhadap kemanusiaan adalah salah satu perbuatan yang dilakukan sebagai bagian dari serangan yang meluas atau sistematik yang diketahuinya bahwa serangan tersebut ditujukan secara langsung terhadap penduduk sipil, berupa;

a. pembunuhan,

b. pemusnahan,

c. perbudakan,

d. pengusiran atau pemindahan penduduk secara paksa,

e. perampasan kemerdekaan atau perampasan kebebasan fisik lain secara sewenangwenang yang melanggara (asas-asas) ketentuan pokok hukum internasional,

f. penyiksaan,

g. perkosaan,

h. perbudakan seksual,

i. pelacuran secara paksa,

j. pemaksaan kehamilan,

k. pemandulanatausterilisasisecarapaksaatau bentuk-bentuk kekerasan seksual lain yang setara,

1. penganiayaan terhadap suatu kelompok tertentu atau perkumpulan yang didasari persamaan paham politik, ras, kebangsaan, etnis, budaya, agama, jenis kelamin, atau alasanlainyang telahdiakuisecarauniversal sebagai hal yang dilarang menurut hukum internasional, 
m. penghilangan orang secara paksa,

n. atau kejahatan apartheid.

Ketentuan dari pasal-pasal ini mempunyai korelasi dengan ketentuan hukum humaniter yang dapat dijadikan alasan yang cukup untuk menghukum setiap individu yang ikut bertanggung jawab atas setiap pelangaran Konvensi Jenewa 1949 yang terjadi di Indonesia.Jenis-jenisperbuatanyangtermasuk kepada kejahatan terhadap kemanusiaan dan kejahatan genosida dalam UndangUndang Nomor 26 Tahun 2000 merupakan "pencaplokan" dari ketentuan dalam Pasal 50 Konvensi Jenewa 1949 dan Pasal 7 Statuta Roma 1998. Walaupun, hingga saat ini, Indonesia belum juga meratifikasi Statuta Roma 1998. Berkembang pendapat bahwa keberadaan Undang-Undang Pengadilan HAM dimaksudkan untuk melindungi pelaku kejahatan HAM di dalam negeri. UU Pengadilan HAM dianggap sebagai upaya Indonesia untuk menghindari campur tangan internasional dalam urusan domestik terkait dengan kejahatan kemanusiaan. Dengan mengadili sendiri pelaku kejahatan HAM berat diharapkan dapat mengurangi intensitas perhatian masyarakat internasional terhadap kejahatan-kejahatan HAM berat khususnya yang terjadi di Timor-Timur pasca jajak pendapat.

Salah satu "terobosan hukum" yang menarik dalam Undang-Undang Nomor 26 Tahun 2000 adalah sebagaimana yang diatur dalam Pasal 43 tentang Pembentukan Pengadilan HAM Ad Hoc :

1. Pelanggaran hak asasi manusia yang berat yang terjadi sebelum diundangkannya Undang-undang ini, diperiksa dan diputus oleh Pengadilan HAM ad hoc.

2. Pengadilan HAM ad hoc sebagaimana dimaksud dalam ayat (1) dibentuk atas usul Dewan Perwakilan Rakyat Republik Indonesia berdasarkan peristiwa tertentu dengan Keputusan Presiden.

3. Pengadilan HAM ad hoc sebagaimana dimaksud dalam ayat (1) berada di lingkungan Peradilan Umum
Pasal 43 ayat (1) diatas menganut asas retroactive, sehingga pelanggaran HAM berat yang terjadi sebelum tahun 2000, dapat diperiksa dan diputus oleh Pengadilan HAM ad Hoc. Namun, tidak seluruh pelanggaran HAM berat yang terjadi sebelum diundangkannya undang-undang pengadilan HAM dapat diperiksa dan diadili oleh Pengadilan Ad Hoc melainkan harus dengan Keputusan Presiden.

Asas retroactive adalah asas hukum yang dapat berlaku surut. Asas ini melihat kepada tindakan diwaktu lampau, yang kemudian dapat tunduk dan diatur kepada peraturan hukum yang disahkan saat ini. ${ }^{42}$ Secara sepintas tampaknya penggunaan asas retroaktif dalam Undang-Undang Pengadilan HAM merupakan pelanggaran hak asasi manusia terdakwa. ${ }^{43}$ Namun, dalam Kasus Abilio Soares, Hakim menyatakan bahwa larangan penggunaan asas retroaktif tidak mengurangi atau mempengaruhi pengadilan atau penghukuman pada pelaku pelanggaran HAM berat. Karena pada waktu dilakukan, perbuatan tersebut sudah merupakan kejahatan menurut prinsip-prinsip hukum umum yang diakui oleh bangsa yang beradab

42 Irsyad Dahri S Suhaeb.(2013). Retrospectivity and Human Rights in Indonesia: How Can Irregularities be Resolved, Indonesian Journal of International Law, Volume 10 Number 2 January, hlm.341.

${ }^{43}$ Walapun beberapa ahli tidak setuju dengan penerapan asas retroaktif dalam peraturan perundang-undangan, namun dalam konteks pelanggaran berat hak asasi manusia, mereka sampai pada pandangan yang sama. Bahwa hal tersebut dapat dibenarkan, selama diatur dalam sebuah undang-undang.

Sebagaimana yang disampaikan oleh Bagir Manan, bahwa "semua aturan hukum hanya berlaku kedepan (prospektif). Hal ini berkaitan dengan salah satu prinsip negara hukum. Suatu hubungan atau peristwa hukum hanya akan mempunyai akibat hukum, berdasarkan aturan hukum (positif) yang ada pada saat hubungan atau peristiwa hukum itu terjadi. Walaupun demikian, dalam halhal terbatas, dimungkinkan penerapan hukum berlaku surut, antara lain : ".. Penerapan hukum secara berlaku surut diperlukan sebagai cara memulihkan dan menegakkan keadilan atas berbagai tindakan yang sangat merugikan atau melukai secara mendalam rasa kemanusiaan suatu lingkungan masyarakat. Inilah dasar yang memungkinkan penerapan hukum berlaku surut atas pelanggaran HAM berat (gross violation of human right) dimasa-masa lalu. Namun, untuk mencegah kesewenang-wenangan, penerapannya harus ditentukan secara ketat baik mengenai perbuatan maupun tata cara pelaksanaannya. Tanpa pembatasan-pembatasan tersebut menimbulkan kesewenang-wenangan dalam penerapan (khusus penegakan) hukum." 
dan telah berkembang dalam masyarakat bangsa-bangsa. ${ }^{44}$ Penerimaan penggunaan asas retroaktif bagi kejahatan paling serius terhadap kemanusiaan telah menjadi preseden internasional sebagaimana yang terjadi pada pengadilan HAM ad Hoc di Rwanda dan Yugoslavia.

Sifat retroaktif dan tidak mengenal kadaluwarsa penuntutan yang dianut dalam Undang-Undang Nomor 26 Tahun 2000 tentang Pengadilan Hak Asasi Manusia mengakibatkan segala bentuk pelanggaran hak asasi manusia yang berat yang dilakukan oleh siapapun yang berumur diatas 18 tahun sebelum Undang-Undang Nomor 26 Tahun 2000 tentang Pengadilan Hak Asasi Manusia diundangkan kedalam Lembaran Negara, dapat dituntut dengan Undang-Undang ini. Pelanggaran hak asasi manusia yang berat yang terjadi di Indonesia pada masa penjajahan pun apabila dimungkinkan dapat dituntut dengan Undang-Undang Nomor 26 Tahun 2000 Tentang Pengadilan Hak Asasi Manusia.

Pun demikian, hingga saat ini, belum ada satupun kasus pelanggaran HAM yang kemudian diadili menurut Undang-Undang Nomor 26 Tahun 2000 tentang Pengadilan HAM. Meskipun, untuk kasus pelanggaran HAM berat, undang-undang tersebut menganut asas retroactive. Pelanggaran HAM berat yang direkomendasikan oleh Komnas $\mathrm{HAM}^{45}$ dan disitir oleh berbagai media dan komunitas internasional sampai detik ini direkognisi berlangsung tanpa pelaku. UU Pengadilan HAM gagal menjadi sistem hukum HAM yang menjamin pengungkapan,

${ }^{44}$ Putusan Nomor1/PID.HAM/AD.HOC.2002.PH.JKT. PST atas Perkara Abilio Jose Osorio Soares dalam Yustina Trihoni Nalesti Dewi, Op.Cit, hlm.221.

${ }^{45}$ Sembilan kasus yang telah diselidiki oleh Komnas HAM, dan menurut laporan Komisi diduga terjadi pelanggaran HAM berat pada kasus-kasus tersebut. Peristiwa-peristiwa yang telah diselidiki oleh Komnas HAM adalah Tragedi Tanjung Priok (1984), Peristiwa Kerusuhan Semanggi Mei (1998), Peristiwa Trisakti (1998), Peristiwa Semanggi I (1998), Peristiwa Semanggi II (1999), Peristiwa Timor Timur (1999), Peristiwa Abepura (2000), Peristiwa Wasior (2001-2002), serta Peristiwa Wamena (2003). penghukuman, dan pemidanaan pelanggaran HAM berat. ${ }^{46}$

Sehingga, dapat dikatakan bahwa adopsi jenis-jenis kejahatan yang termasuk kedalam pelanggaran berat Konvensi Jenewa dalam Undang-Undang Nomor 26 Tahun 2000, hingga saat ini tidak berjalan secara efektif. Belum ada satu orangpun yang diadili dan bertanggungjawab terhadap kasus-kasus pelanggaran HAM berat di Indonesia merupakan bukti nyata bahwa ada banyak kelemahan baik secara substansi maupun prosedur penegakan hukum dalam UndangUndang Nomor 26 Tahun 2000.

Oleh karena itu, pelaksanaan kewajiban Indonesia berdasarkam common articles Pasal 49 Konvensi Jenewa I, Pasal 50 Konvensi Jenewa II, Pasal 129 Konvensi Jenewa III dan Pasal 146 Konvensi Jenewa IV merupakan "pekerjaan rumah" yang harus segera diselesaikan, dalam rangka menjamin penghormatan terhadap Konvensi Jenewa 1949. Penghormatan terhadap Konvensi Jenewa 1949 merupakan kewajiban utama negara, sebagaimana yang tercantum dalam Pasal 1 Konvensi Jenewa 1949.

Salah satu langkah yang dapat dilakukan oleh pemerintah Indonesia untuk menjamin penghomatan Konvensi Jenewa 1949 adalah dengan pembentukan undang-undang khusus. Dengan undang-undang tersebut, diharapkan akan tersedia jenis pidana sebagaimana yang tercantum dalam Pasal 50 Konvensi Jenewa I dan mekanisme penegakkan hukum yang tepat. Sehingga, secara nasional dan internasional, Indonesia pada akhirnya mampu menyelidiki, mengadili dan menghukum pelaku pelanggaran HAM berat.

\section{KESIMPULAN}

Telah cukup lama sejak Indonesia mengesahkan Konvensi Jenewa 1949 dengan Undang-Undang Nomor 59 Tahun 1958 tentang Ikut Serta Negara Republik

$46 \quad$ Halili.(2016). Politik Penegakan Hak Asasi Manusia Pada Masa Transisi Di Indonesia, Jurnal Civics Volume 13 Nomor 2, Desember, hlm. 206. 
Indonesia dalam Seluruh Konvensi Jenewa tanggal 12 Agustus 1949. Sebagai sebuah perjanjian internasional, Konvensi Jenewa 1949 menghendaki setiap negara yang telah mengesahkan membuat undang-undang nasional tentang pelaksanaan ketentuanketentuan konvensi di dalam hukum nasional. Salah satunya adalah ketentuan-ketentuang yang bersamaan (common articles) dalam Pasal Pasal 49 Konvensi Jenewa I, Pasal 50 Konvensi Jenewa II, Pasal 129 Konvensi Jenewa III dan Pasal 146 Konvensi Jenewa IV tentang kewajiban negara peserta untuk menerapkan sanksi pidana efektif bagi pelaku pelanggaran berat.

Enam puluh tahun kemudian, saat sekarang, dapat dikatakan kewajiban Indonesia berdasarkan common articles Pasal 49 Konvensi I, belum juga dapat dilaksanakan secara efektif. Jika bisa dikatakan bahwa, Undang-Undang PengadilanHAMmerupakan implementasi Konvensi Jenewa 1949 karena beberapa jenis kejahatan yang diatur dalam undang-undang tersebut merupakan "adopsi" Konvensi Jenewa 1949. Namun, dalam tataran praktik, belum ada satu orangpun yang diadili atas kasus-kasus pelanggaran berat HAM yang terjadi di Indonesia. Pemerintah seolah setengah hati untuk melaksanakan kewajibannya berdasarkan common articles Pasal 49 Konvensi Jenewa I.

\section{DAFTAR PUSTAKA}

\section{Buku}

Arie Siswanto.(2015). Hukum Pidana Internasional, Penerbit Andi, Yogyakarta

Arlina Permanasari, 1999, Pengantar Hukum Humaniter, Jakarta: ICRC.

Ambarwati, dkk.(2009). Hukum Humaniter Internasional (Dalam Studi Hubungan Internasional), Jakarta: Rajagrafindo Persada.

Direktorat Jenderal Hukum dan Perundangundangan Departemen Kehakiman, 1999, Terjemahan Konvensi Jenewa
1949, Jakarta.

KGPH Haryomataram.(2005). Pengantar Hukum Humaniter, Jakarta: PT. Rajagrafindo Persada.

Starke, JG,(1997). An Introduction to International Law, London:

Butterworths.

Yustina Trihoni Nalesti Dewi.(2013). Kejahatan Perang dalam Hukum Nasional dan Hukum Internasional, Jakarta: Rajagrafindo Persada.

\section{Artikel Jurnal}

Dina Sunyowati. (2013). Hukum Internasional Sebagai Sumber Hukum Dalam Hukum Nasional (Dalam Perspektif Hubungan Hukum Internasional Dan Hukum Nasional Di Indonesia), Jurnal Hukum dan Peradilan, Volume 2 Nomor 1 Maret .

Endra Wijaya, dkk.(2017). Dinamika Upaya Melakukan Sinergi Antara Hukum Perdagangan Internasional Dan Hukum Lingkungan, Jurnal Hukum dan Peradilan Volume 6 Nomor 3, November.

Erlies Septiana Nurbani.(2017). Perkembangan Teknologi Senjata dan Prinsip Proporsionalitas, Jurnal Ius (Kajian Hukum dan Keadilan) Volume 5 Nomor 1 .

Sadikin.(2009). Ratifikasi Perjanjian Internasional dalam Kaitannya dengan Program Legislasi Nasional, Makalah dalam FGD Ratifikasi OP CEDAW.

Erwin. Pengabaian Distinction Principle dalam Situasi Blokade oleh Israel di Jalur Gaza, tanpa tahun, tanpa penerbit.

Mahfud. (2013) .Integrasi HAM Dan Hukum Humaniter Dalam Sistem Peradilan Ham Nasional Dalam Rangka Penerapan Peradilan Ham Terhadap Pelaku Kejahatan Kemanusiaan, 
Kanun Jurnal Ilmu Hukum No. 61, Th. XV.

Muladi.(2003). Peradilan Hak Asasi Manusia

Dalam Konteks Nasional dan Internasional, Artikel Lepas, Jakarta.

Irsyad Dahri S Suhaeb.(2013). Retrospectivity and Human Rights in Indonesia : How Can Irregularities be Resolved. Indonesian Journal of International Law, Volume 10 Number 2 January.

\section{Internet}

Kompas, 21 April 2016 diakses melalui https://ebooks.gramedia.com/id/ koran/kompas/pagi-21-apr-2016 pada tanggal 29 Januari 2018.

\section{Peraturan perundang-undangan}

Undang-undang Nomor 26 Tahun 2000 tentang Pengadilan Hak Asasi Manusia

Undang-undang Nomor 24 Tahun 2000 tentang Perjanjian Internasional

Undang-Undang Nomor 59 tahun 1958 tentang Ikut Serta Indonesia dalam seluruh Konpensi Jenewa 1949. 